\title{
Drivers of Use of Information and Communication Technologies by Farm Households: The Case of Smallholder Farmers in Kenya
}

\author{
Julius J. Okello (Corresponding Author) \\ University of Nairobi, P.O. Box 29053, Nairobi, Kenya \\ Tel: 254-727-869-515 E-mail: jjokello@gmail.com \\ Oliver K. Kirui \\ International Centre for Maize and wheat Improvement, P.O. Box 1041, Nairobi, Kenya \\ Tel: 254-723-804-178Ｅ-mail: oliverkk@yahoo.com \\ Georgina W. Njiraini \\ University of Nairobi, P.O. Box 29053, Nairobi, Kenya \\ Tel: 254-722-841-016_E-mail: ginawams2004@yahoo.com \\ Zachary M. Gitonga \\ International Centre for Maize and Wheat Improvement, P.O. Box 1041, Nairobi, Kenya \\ Tel: 254-711-875-474 E-mail: gitongamzachary@yahoo.com
}

Received: June 20, 2011

Accepted: July 7, $2011 \quad$ Online Published: December 21, 2011

doi:10.5539/jas.v4n2p111

URL: http://dx.doi.org/10.5539/jas.v4n2p111

The authors acknowledge funding for this study from the International Development Research Center through Grant No. 104482-001

\begin{abstract}
Smallholder farmers' access to markets has traditionally been constrained by lack of market information. The desire to strengthen farmer access to market has seen the emergence of a number of projects that employ ICT tools in the provision of market information. This study assesses the conditioners of the use of ICT tools in general and mobile phones in particular by smallholder farmers for agricultural transactions. The study finds that several farmer, farm and capital endowment factors affect the use of ICT tools and mobile phones. Specifically, age, occupation, nearness to output market, number of crop enterprises, farming experience literacy and crop income explain the use of tools while gender, nearness to output market, household size, owning a phone, level of literacy, crop income and value of assets explain the intensity of use of the mobile for agricultural transaction purposes. It discusses the implications of these findings for policy.
\end{abstract}

Keywords: Agricultural transactions, Farmers, Use of ICT tools, Kenya

\section{Introduction}

Market access is one of the most important factors influencing the performance of smallholder agriculture in developing countries, and in particular least developed countries (Barrett, 2008; Kirsten, 2010). Access to new and better-paying markets for agricultural products is vital in enhancing and diversifying the livelihoods of poor subsistence or semi-subsistence farmers (Barrett, 2008). Such markets can be local (including village markets), catering for the local populations, regional markets that serve regional consumers in counties/districts/provinces within one country or between countries, and international/export markets in both developed and developing countries. 
Smallholder producers form the majority of both the total and rural poor in many developing countries, especially Africa. Most smallholder farmers are engaged in subsistence and semi-subsistence agriculture with low productivity, low marketable surplus (hence low returns) and low investment, a situation described as low equilibrium poverty trap (Barrett \& Swallow, 2006; Barrett, 2008). Enhancing returns from agricultural production through improved access to markets can therefore be a vital element of poverty alleviation strategy and livelihood improvement in these countries. Improved market access results in commercialization of agriculture, which has short, medium, and long-term benefits to farmers. In the short term, market access can result in the production of marketable surplus and hence gains in income from agriculture. In the medium to long-run, the surplus from improved market access can result in higher revenues, savings and hence investment in productivity enhancing technologies. The effect of market access for smallholder farmers is even greater for high-value commodities (i.e., non-traditional, non-staple crops such as high-value fruits and vegetables and organic products). Access to markets for high value commodities has multiple benefits to smallholder producers (Okello, 2005; Okello \& Swinton, 2007). Such benefits include direct income for smallholder producers and the indirect impacts at both the household and community levels in terms of employment.

Despite its importance, market access in many developing countries remains severely constrained by poor access to agricultural and market information. Poor access to market information results in information-related problems namely moral hazard and adverse selection which in turn increase transaction costs and hence discourage participation in the market by some farmers (Omamo, 1998; Fafchamps \& Hill, 2005; Shiferaw, Obare \& Muricho, 2009). Recent attempts to resolve the problem of poor access to better performing markets by smallholder farmers have thus focused on promoting information transfer through ICT-based innovations (Tollens, 2006; Aker, 2008). These innovations include mobile telephony, internet/web-based means, and interactive video and CD-ROM programs as well as older ICT-based technologies namely the radio and television (Munyua, 2007). The promotion of these mostly new generation ICT tools especially the mobile phones stems from its rapid penetration in Africa and increased ownership by rural households (Okello et al., 2010)

The increased focus on modern ICT-based methods of information provision comes from the realization that they can play a major role in i) communicating knowledge and information to rural farmers, ii) delivering education and training modules to farmers at low cost, iii) improving smallholder farmers' access to markets and agricultural credit, iv) empowering farmers to negotiate better prices, and v) facilitating and strengthening networking among smallholder farmers. Despite the great enthusiasm by development agencies in promoting the application of ICT tools in transferring agricultural information to farmers, little is known about the use of these tools for agricultural transactions. This study examines the factors that condition the use of ICT tools for agricultural transactions by assessing the factors that affect the use of mobile phones, the most widely owned and used new generation ICT tool among farm households, for agricultural transactions.

This study focuses primarily on smallholder farmers. It uses data collected from smallholder farmers stratified by participation in ICT-based Market Information Service (MIS) projects. The rest of this paper is organized as follows: Section 2 presents the conceptual framework of the study. Section 3 presents the study results while Section 4 concludes.

\section{Conceptual and empirical methods}

\subsection{Conceptual framework}

This study uses the Transaction Cost Economics (TCE) theory, which is part of the New Institutional Economics (Hubbard, 1997; Clague, 1997; Poulton, Dorward \& Kydd, 1998). The concept of transaction costs was first introduced by Coase (1937) and has since been widely used in studies in agricultural economics and related fields in developing countries (Jaffee, 2005; Fafchamps, 2004; Fafchamps \& Hill, 2005; Okello \& Swinton, 2007).

Transaction cost is loosely defined as cost of doing business or cost of exchange between two trading partners, in our case farmers and buyers. It posits that difficulties in economic exchange between two partners arise because of exchange related problems that include asymmetric information. In small farm situation, asymmetric information arises when either the farmer or buyer lacks essential information relating to the exchange. The more informed party therefore takes advantage of the exclusively available information to benefit him/herself, a situation referred to as opportunism and has been defined by Williamson (1985 p. 45) as "self-interest seeking with guile" (Miller, 2005). In the case of agriculture where smallholder farmers tend to be less informed than traders/buyers, the latter can use the exclusively available information (about price, supply condition, or quality) to benefit themselves. One way to deal with this problem is to agree on terms of exchange beforehand. However, 
while the terms of the exchange can be specified a priori (i.e., through a contract), the uncertain nature of future outcomes makes it impractical to write complete contracts resulting instead in the use of informal agreements (i.e., incomplete contracts) (Williamson, 2000; Menard, 2005). That is, even though economic agents may be rational in their decision-making, they are bounded by the uncertainty of future outcomes. Under such circumstances, the buyer even with a priori agreement on terms of exchange can take advantage of the farmer by engaging in actions that are contrary to the specifications of the agreement, a condition known as moral hazard. Alternatively, the buyer may claim ability to meet the terms of the agreement (e.g., buy the entire commodity from the farmer) only to fail to do so due to changes in the market, a situation called adverse selection. These conditions prevail in many farming environments in Africa where agricultural information is generally unavailable and has been one of the factors behind the push for ICT-based projects.

Lack of information between the seller (farmer) and the buyer make the exchange of goods (i.e., trade) more costly (Williamson, 2004). Coase (1937) argued that these costs of exchange include search and screening costs, negotiation costs, costs of monitoring and enforcing terms of agreement, and costs of adapting to change in market environment (also known as mal adaptation costs). Farmers who need to sell some produce must search for buyers and screen-off unreliable or opportunistic ones thus incurring search and screening costs. Once the buyer is identified, the farmer has to negotiate the terms of sale (i.e., price, quantity, quality, time of sale, frequency of sale, etc). The farmer thus incurs costs relating to time spent and financial outlays in negotiating the terms of exchange. A farmer may then have to engage in follow up activities (i.e., monitor) the buyer to ensure that the latter meets the terms of exchange and hence incurs monitoring costs. The farmer may also have to spend time and resources getting the buyer to honor the terms of agreement thus incur enforcement costs. Lastly, in the longer term agreements, changes in market condition may dictate adjustments in the terms of exchange such as the sales volume, quality, price, and frequency or time of sale. The farmer may thus incur monetary or time costs (i.e., mal-adaptation costs) during the renegotiation of the terms of exchange. These four categories of transaction costs are prevalent in both input and output markets in Africa. Poulton, Kydd \& Dorward (2006), Fafchamps (2004), and Fafchamps \& Gabre-Madhin (2006) for instance highlight some of these costs in relation to African farmers and traders.

The bottom-line is that lack of market information increases the costs of exchange between the farmer and buyer. Smallholder farmers are especially disadvantaged because they trade in small volumes, usually in local markets, hence are not able to take advantage of economies of scale to reduce the fixed transaction costs of exchange with buyers. At the same time, smallholder farmers, due to their geographic dispersion, incur higher variable transaction costs of accessing agricultural inputs and selling their produce. Theoretically, households that use market information services provided by ICT-based projects are expected to face lower transaction costs. Unlike their counterparts, such farmers are likely to use the services offered by the project to resolve some of the idiosyncratic market failures resulting from high transaction costs.

Assume that the farmer minimizes the total cost of production which includes both conventional and transaction costs subject to conventional constraints. The farmer chooses agricultural information $\mathbf{I}$ alongside other inputs to minimize the combined conventional and transaction cost. Algebraically the farmer minimizes,

$$
\mathrm{C}(\mathbf{W}, \mathbf{X})
$$

Subject to a production function specified as:

$$
\mathrm{q}(\mathbf{X})=\mathrm{q}(\mathbf{V}, \mathbf{I}(\mathbf{T}), \mathbf{L}, \mathbf{K}, \mathbf{z})
$$

where $\mathrm{C}$ is the total input cost including transaction costs, $\mathbf{W}$ is a vector of input prices; $\mathbf{X}$ is vector of all production inputs; $\mathbf{V}$ is a vector of conventional variable inputs such as, fertilizer, seed, and pesticides used by the farmer; $\mathbf{q}$ is the output produced and sold using agricultural information I whose use embodies the use of ICT tools (T) including the mobile phones, radio, and computer based applications (e.g., email); $\mathbf{L}$ is the total labor requirement including both family $(l)$ and hired labor $(h)$. Lastly, $\mathbf{K}$ and $\mathbf{z}$ are fixed and quasi-fixed capital inputs and institutional factors, respectively.

The farmer's optimization problem therefore is to choose I to minimize the total cost of production subject to labor availability and a specified quantity of output $\mathbf{q}^{\mathbf{0}}$. That is;

$$
{ }_{I}^{\operatorname{Min}} C(.)=[W V+W I(T)+W L]
$$

Subject to:

$$
q \geq q^{0}
$$




$$
L \geq l+h
$$

Equation (4) shows that the output constraint need not hold exactly whereas equation (5) indicates that the family labor and the hired labor altogether should at least equal the total effective labor requirement.

Solving the Lagrangian expression associated with the cost minimization problem above, and assuming that the second order sufficient condition is satisfied, yields, among others, $\mathrm{T}^{*}$ which is conditional input demand equation (associated with ICT tools) as functions of output $\mathbf{q}$, input prices $\mathbf{W}$, convectional variable inputs $\mathbf{V}$, fixed factors $\mathbf{K}$ and institutional factors $\mathbf{z}$. That is:

$$
\mathrm{T}^{*}=\mathrm{T}^{*}(\mathrm{~W}, \mathrm{q}, \mathrm{V}, \mathrm{K}, \mathrm{z}) .
$$

Equation (6) above also gives the adoption function related to the use of ICT tools and mobile phones which is embodied in the use of ICT-based agricultural information.

\subsection{Empirical methods}

In this section we first layout the empirical methods used in analyzing the conditioners of used of ICT tools. We then proceed to examine the factors affecting the use and intensity of use of mobile phones by small farm households for agricultural transactions. Lastly, we describe the sampling procedure and data.

\subsubsection{Drivers of use of ICT tools (or mobile phones) in agriculture}

The use of ICT tools by farmers is measured in this study using a dichotomous (binary) choice variable of "Yes" or "No" type indicating the use or none use of ICT tools by a farmer, respectively. The most commonly used approaches for estimating such discrete dependent variable regression models are the Logit and Probit regression techniques (Liao, 1994; Maddala, 2001; Gujarati, 2004). Liao (1994) and Gujarati (2004) argue that the Probit and Logit models are similar and generate predicted probabilities that are almost identical. Aldrich and Nelson (1984) also indicate that, in practice, these models yield estimated choice probabilities that differ by less than 0.02 . The main difference between the two is in the nature of their distribution which is captured by cumulative distribution function (CDF). The Probit has a normal distribution while Logit has a logistic (slightly fatter tail) distribution. The choice between Probit and Logit regression model depends, therefore, on the distribution assumption one makes. In practice many researchers choose the Logit model because of its comparative mathematical simplicity. Sirak \& Rice (1994) however argue that the Logit regression model is more powerful, convenient and flexible and is often chosen if the predictor variables are a mix of continuous and categorical variables and/or if they are not normally distributed. Some of the predictor variables in this study are categorical and therefore this study uses the binary Logit regression model to identify the drivers of use of ICT tools (and also mobile phones).

Following Maddala (2001), the probability, $p$, that a household uses an ICT tool (and/or a mobile phone) for agricultural purposes is given by:

$$
P=e^{z} / 1+e^{Y}
$$

Central to the use of logistic regression is the Logit transformation of $p$ given by $Y$

$$
Y=\ln (p / 1-p)
$$

Where;

$$
Y=Y(F, R, K, L)+\varepsilon
$$

and $\mathrm{Y}$ is a latent variable that takes the value of 1 if the farmer uses an ICT tool (or a mobile phone) and 0 otherwise.

The vector $\boldsymbol{F}$ in Equation (9) represents farmer-specific characteristics, while $\boldsymbol{R}$ is a vector of farm-specific variables, $\boldsymbol{K}$ is a vector of capital endowments, $\boldsymbol{L}$ is a vector of location/district level characteristics and $\varepsilon$ is the stochastic term assumed to have a logistic distribution. The empirical model estimated contains the following variables):

1) Farmer specific variables $(\boldsymbol{F})=\log$ of age, gender, and occupation

2) Farm specific variables $(\boldsymbol{R})=$ distance to output market, number of crop enterprises, household size and distance to electricity

3) Capital endowment variables $(\boldsymbol{K})$ :

a. Physical asset: log of crop income, log of assets, log of land, owning a mobile phone

b. Human capital: literacy, log of farming experience 
c. Social capital: group membership

4) Location variables $(\boldsymbol{L})$ :

a. Region of survey: Mt. Kenya and Western regions

b. District: Kirinyaga, Bungoma and Migori districts

The implicit functional form estimated to assess the drivers the decision to use ICT tools or mobile phones by a farmer is given by:

use of ICT tools (or mobile phone) $=f$ (log of age, gender, occupation, fare to output market, distance to electricity, number of crop enterprises, household size, log of crop income, log of assets, area cultivated, literacy, log of farming experience, own phone, group membership, district dummies) $+e$

\subsubsection{Intensity of mobile phone use for agricultural transactions}

The intensity of mobile phone use for agricultural transactions in this study refers to the number of calls made and received by a farmer for agricultural purposes. They include calls made to and those received from produce buyer/ trader, agro-input dealer, financial service provider and information services. The number of calls made by a farmer assumes integer values of discrete nature and is therefore a nonnegative count variable. Count data are non-normal and hence are not well estimated by Ordinary Least Squares (OLS) regression (Maddala, 2001)

The most common regression models used to analyze count data models include the Poisson Regression Model (PRM), the Negative Binomial Regression Model (NBRM), the Zero Inflated Poisson (ZIP) and the Zero Inflated Negative Binomial (ZINB). The PRM and NBRM regression models have become the standard models for the analysis of response variables with nonnegative integer (Winkelmann and Zimmermann, 1995; Greene, 2008; Kirui, Okello \& Nyikal, 2010). The last two (ZIP and ZINB) are specifically used to account for cases with frequent zero counts (i.e. when there are more zeros than would be expected), which is not the case in this study. Only the PRM is therefore discussed here since the response variables were nonnegative integers and with only a few zero counts. In addition, test of overdispersion and underdispersion, common problems that render estimates of PRM biased and inefficient and justify the use of NBRM, found absence of these problems in the estimated PRM.

Greene (2008) argues that PRM models (for analyzing count data) are much closer to OLS regression model than other discrete choice models. This is because, just like OLS, the optimality conditions can be derived from the PRM models and that violation of variance assumptions in the models does not necessarily result in inconsistent estimators but rather the coefficient estimates are inefficient and standard errors are potentially biased (Wooldridge, 2002). Poisson regression model is therefore normally the first step for most count data analyses (Areal, Touza, McLead, Dehnen, Perrings, Palmieri \& Spence, 2008). Its density function of PRM is given by (Greene, 2003 \& 2008; Wooldridge, 2002):

$$
f\left(y_{i} \mid x_{i}\right)=\frac{e^{-\lambda(x)} \lambda_{i}(x)^{y}}{\Gamma\left(1+y_{i}\right)}
$$

Where $\quad \lambda_{\mathrm{i}}=\exp \left(\alpha+\mathrm{X}^{\prime} \beta\right)$ and $\quad \mathrm{y}_{\mathrm{i}}=0,1, \ldots, i$ is the number/count of services used (in our case); $\mathrm{X}=$ a vector of predictor variables.

Wooldridge (2002) and Greene $(2003 ; 2008)$ show that the expected number of the events, $y_{i}$ (i.e., number of calls made) per period is given as:

$$
E\left(y_{i} \mid x_{i}\right)=\operatorname{var}\left[y_{i} \mid x_{i}\right]=\lambda_{i}=\exp \left(\alpha+\mathrm{X}^{\prime} \beta\right) \quad \text { for } i=1,2, \ldots, n .
$$

The log-linear conditional mean function $E\left(y_{i} \mid x_{i}\right)=\lambda_{i}$ and its equi-dispersion $\operatorname{Var}\left(y_{i} \mid x_{i}\right)=\lambda_{i}$ assumptions constitute the main features of Poisson regression model (Greene, 2008). The log-linear regression models accounts for the nonnegative restriction imposed by Poisson on the dependent variable (Winkelmann and Zimmermann, 1995). Based on Equation (12), we specify the implicit functional form of the model estimated to examine the intensity of use of the mobile phone for agricultural purposes as;

Number of calls $=f$ (log of age, gender, occupation, fare to output market, distance to electricity, number of crop enterprises, household size, log of crop income, log of assets, area cultivated, literacy, log of farming experience, own phone, group membership, district dummies) $+e$ 


\subsection{Sampling procedure and data}

This study uses data collected from smallholder farmers located in Kirinyaga, Bungoma and Migori districts. The districts were selected for the survey because they hosted an ICT-based market information project, namely the DrumNet project, between 2004 and 2007. They are therefore likely to have benefited from the demonstration effects of the project. The districts were also selected to capture diverse social and economic backgrounds. Kirinyaga district has export-oriented agriculture with several export crops (French beans, various Asian vegetables and baby corn) being produced by the farmers that were targeted with the project. Smallholder farmers in Bungoma district grow mainly maize (a lower value crop) with some sugarcane. In Migori, on the other hand, the main crops are maize and tobacco. Thus the choice of the districts provides diverse socio-economic and cultural backgrounds. Okello, Ofwona-Adera \& Mbatia (2010) give detailed background of the DrumNet project.

The study targeted smallholder farmers including those who participated in ICT-based projects that used ICT-based tools and those who did not. The respondents in this study were therefore stratified by participation in such ICT-based agricultural projects.

The sampling procedure was done in three stages. First, in each district, an area with an ICT-based project was identified. Second, for each such area, a list of all farmers participating in the ICT-based projects was drawn with the help of project and farmers' leaders. A second list of farmers that did not participate in the ICT-based projects was also obtained with the help of local administration (i.e., village headmen) and area agricultural extension officers and validated by project and farmers' leaders as non-project members. Third, the respondents were sampled from the two lists using probability proportionate to size sampling method. That is, more farmers were sampled from the list with more names. This procedure resulted in 162 farmers who had participated in ICT-based interventions and 216 non-participants. A total of 379 farmers were therefore interviewed in this study. This comprised of 127, 130 and 122 respondents from Kirinyaga, Bungoma and Migori districts, respectively. The data was collected through personal interviews using a pre-tested questionnaire. The data collected included farmer-specific characteristics, farm-specific characteristics, household capital/asset endowments, and location characteristics. The household survey was conducted in April and May 2010. Definition of the variables collected during the study and applied in the econometric models is given in Table 1, while Table 2 gives summary statistics of variables used in estimating the regression models.

$<$ Table 1>

Results in Table 2 show that the mean number calls made and the decision to use the mobile phone for agricultural transaction purposes is 6.09 and 0.464 , respectively. The $t$ values suggest that there are significant differences in the variables used for empirical analysis namely the farm, farmer, capital and location variables.

$<$ Table 2>

\section{Results and discussions}

\subsection{Use of ICT tools for agricultural transactions}

The results of the Logit regression model estimated to assess the drivers of use of ICT tools for agricultural transactions along with the marginal effects are presented in Table 3.

$<$ Table 3>

As shown, a number of factors condition the use of ICT tools. Notably, among the farmer-specific characteristics, age and primary occupation of the respondent are significant in influencing the decision to use ICT tools. A unit increase in the natural log of age decreases the likelihood of a farmer using ICT tools by 0.296 , holding other factors constant. This finding indicates that the use of ICT tools for agricultural transactions is greater among the younger farmers which corroborates the findings of past studies suggesting that this category of farmers are more literate and better able to use ICT (Okello, Ofwona-Adera \& Mbatia, 2010). Similarly, other things constant, the likelihood of using ICT tools is higher by 0.251 among farmers that practice farming as a primary occupation than their counterparts probably because farmers who engage in farming full time are more likely to produce more and hence will need to seek input and output information from multiple sources using multiple strategies including ICT tools. Among the farm specific variables, nearness to output market, distance to electricity source and the number of crop enterprises grown by the farmer are significant in influencing the decision to use ICT tools. Specifically, a unit increase in the cost of transport to output market increases likelihood of using ICT tools by 0.002 suggesting that ICT tools are an important option for cutting down on transaction costs incurred in obtaining market information. Other things constant, an increase in the number of crop enterprises a farmer has a 
proxy for risk aversion, decreases the likelihood of using ICT by 0.048 . This finding suggests that farmers who are risk averse are less likely to use ICT tools for agricultural transactions.

Results further show that, among capital endowment variables, literacy and crop income positively influence the decision to use ICT tools. Holding other things constant, ability to read and write and the natural $\log$ of crop income increase the likelihood of using ICT tools by 0.159 and 0.017 , respectively. The finding with respect to literacy further supports our earlier finding that the younger, and hence more educated, farmers are more likely to use ICT tools for agricultural transactions compared to their counterparts. Results however show that endowment with physical assets reduces the likelihood of using ICT tools. While this finding was unexpected, it may suggest that farmers that are more asset-endowed are more able to travel to distant markets without the need to use ICT tools. Indeed, this study finds that travel to market to "ask-around" for information was the most preferred alternative way of seeking market information among the respondents. In addition, the finding that asset endowment reduces the likelihood of using ICT tools may also mean that such farmers will usually have prior marketing arrangements (such as purchase contracts) with dedicated customers hence do not need to seek for information at the time of sale (usually after harvest). Among the location variables, the coefficients of the two dummies representing the districts the study was conducted in are statistically significant but with different signs. Specifically, the results show that moving from Bungoma to Kirinyaga increases the likelihood of using ICT tools for agricultural transaction. This finding is in line with our apriori expectations. Farmers in Kirinyaga produce market-oriented export vegetables hence are more likely to use ICT tools such as mobile phones and computer-based applications such as emails for transacting business. The results also show that farmers in Migori are less likely to use ICT for agricultural transactions than their counterparts in Bungoma suggesting that farmers who grow mostly subsistence crops (a common practice in Migori) are less likely to use ICT tools for agricultural transactions.

\subsection{Factors affecting the use and intensity of use of mobile phones for agricultural transactions}

Results of the double hurdle model estimated to examine the factors affecting the use and extent of use of mobile phones for agricultural transactions are given in Table 4

$<$ Table 4>

As shown, a number of factors influence the use the mobile phone for agricultural transaction purposes. Among the farmer-specific characteristics, age and gender of the respondent are significant in influencing the decision to use the mobile phones for agricultural transactions. The finding that use of mobile phone is inversely related to age, again, implies that younger farmers are more likely to use these tools for agricultural transactions than their older counterparts which supports the finding of past studies suggesting that this category of farmers are more literate and better able to use ICT tools, the mobile phone being one of these tools (Okello, Ofwona-Adera \& Mbatia, 2010). Similarly, other things constant, the likelihood of using a mobile phone for agricultural transactions is higher among the male headed households that practice farming than their counterparts. This finding is in line with common practice among rural farm households in Kenya which puts the responsibility of buying inputs and arranging sale of output on male household heads.

Among the farm specific variables, close proximity to output market and household size are significant in influencing the decision to use the mobile phone. Specifically, an increase in the cost of transport to an output market increases the likelihood of using mobile phones for agricultural purposes suggesting that mobile phones offer an opportunity to reduce the transaction costs of obtaining market information. Results also show that an increase in the size of a household reduces the likelihood of using the mobile phone for agricultural transactions. This finding suggests that larger households are less likely to use mobile phones for agricultural transactions probably because they have less surplus produce to sell hence will make fewer agricultural-related transaction calls. Distance to the electricity source is inversely related to the use of mobile phones for agricultural-related transactions. This finding suggests that electricity connectivity in the rural areas would increase the use of mobile phones by farmers. This is because the mobile phones available in the Kenyan market still rely on electricity for charging the batteries when they run out of power.

Results further indicate that, among capital endowment variables, literacy, farming experience, asset value and crop income positively influence the decision to use the mobile phone. Holding other things constant, the level of literacy and the natural log of crop income both increase the likelihood of using the mobile phone for agricultural transactions. The finding with respect to literacy further supports the above finding that the younger and hence more educated farmers are more likely to use the mobile phone for agricultural transactions compared to their counterparts. Results further show that holding other factors constant, endowment with physical assets and farming experience increase the likelihood of using the mobile phone for agricultural transactions. Farmers with 
more physical assets that can be deployed for agricultural production and marketing of agricultural surpluses (such as hoes, bicycles, television, mobile phone, and ox-cart) are more likely to produce more output and hence participate more in the market than their counterparts. Among the location variables, results show that farmers in Migori are less likely to use the mobile phone for agricultural transactions than their counterparts in Bungoma suggesting that farmers who grow mostly subsistence crops (a common practice in Migori) are less likely to use mobile phones for agricultural transactions.

Results of the Poisson regression model estimated to examine the factors affecting the extent of use of mobile phones for agricultural transactions are also presented in Table 4. Among the farmer-specific variables, gender affects the intensity of use of the mobile phone. The expected number of calls made and/or received is 0.23 times higher among the males than female farmers. This finding further supports our earlier argument that the culture among rural farmers which puts the responsibility of buying inputs and arranging sale of output on men does affect the use of ICT tools such as mobile phones. The results also show that, among farm-specific variables, distance to output market and household size affect the extent of mobile phone use for agricultural transactions. Other things constant, an increase in cost of transport to output market by Kshs 100 increases the expected number of agricultural-related calls by 3.7 percent. While this finding was expected, it suggests that farmers will opt to call transaction partners more often than travel to market to obtain market information only when the cost of travelling to the market becomes relatively large. On the other hand, an increase in household size by one person decreases the number of calls made for agricultural purposes by 12 percent. Considering that the average household size in the study area was relatively large (about 6 members), this finding further indicates that larger households have less surplus to sell in the market hence will make fewer agricultural-related calls than households with fewer members, other things constant.

A number of capital endowment variables namely, literacy, owning a mobile phone and endowment with physical assets also condition the extent of using mobile phones for agricultural transactions. As shown, farmers who are literate use mobile phones for agricultural transactions much more than their counterparts. The results also indicate that increasing the log of crop income and the log of asset value by one unit increase the expected number of calls made for agricultural transactions by 5.3 and 14.4, respectively. Results further indicate that a unit increase in value of crop outcomes also increase the likelihood of making more calls while higher values of assets would tend to increase the number of calls made by $64.4 \%$, holding other factors constant. Overall, increased literacy levels, higher values of crop incomes and assets all increase the number of calls made, again highlighting the importance of investments in capital in facilitating increased use of mobile phones for agricultural transactions. These findings imply that farmers with higher capital endowments tend to make more calls for agricultural purposes hence reducing their costs of exchange which motivates them to participate in the market.

\section{Summary, conclusions and recommendations}

This study assesses the drivers of the use of ICT tools in general and mobile phone in particular for agricultural transactions by smallholder farmers in Kenya. It uses a Logit regression model to examine the factors driving use of ICT tools and a double hurdle model to assess the conditioners of use and intensity of use of the mobile phones for agricultural transactions. The double hurdle model encompassed the estimation of a Logit model to examine drivers of the decision to use mobile phones for agricultural transactions and the Poisson regression model to assess the factors that determine the intensity of use of the mobile phone for the same purpose.

The study finds that the decision to use ICT tools is affected by age, primary occupation of the farmer, the cost of transport to the output market, nearness to electricity for charging phone batteries, the number of crop enterprises, farming experience, literacy levels, crop income and asset value. The study also finds that the decision to use the mobile phone is driven by age, gender, cost of transport to the output market, household size, owning mobile phone, farming experience, literacy levels, crop income and asset value. The study further finds that gender of the household head, fare to the nearest output market, literacy level of the household head, the household size, use of own mobile phone for making calls and endowment with physical and financial assets affect the intensity of using mobile phones for agricultural transactions. These findings indicate that the use of ICT tools in general and mobile phones in particular are driven by a number of farmer specific and farm specific variables as well as capital endowment and location variables. They also suggest that farmers use ICT tools and especially mobile phones to reduce the costs of access to market information

The implication of these findings is that the use ICT tools in general and mobile phones in particular, can help resolve the idiosyncratic market failures that smallholder farmers face due to lack of access to market information. These findings therefore suggest the need for policymakers and the private sector to invest in making access to ICT 
tools by smallholder farmers easier. The finding that literacy conditions the use of ICT tools is not new, but highlights the need to design tools that can be more easily used by the usually less educated smallholder farmers. Another important finding of this study is the importance of electricity. Past studies have suggested the difficulty farmers have in accessing electricity for powering their ICT tools. Hence there is need to design phones that can be solar-powered to reduce dependence on electricity which is usually less available in rural areas.

\section{References}

Aldrich, J. H., \& Nelson, F. D. (1984). Linear probability, logit and probit models. Newbury Park, CA: Sage.

Aker, C.J. (2008). 'Does Digital Divide or Provide?' The Impact of Cell Phones on Grain Markets in Niger; Center for Global Development Economics Department, Fletcher School of Law and Diplomacy, Tufts University.

Areal, F.J., Touza J., McLeod, A., Dehnen-Schmutz K., Perrings, C., Palmieri, M.G., \& Spence N.J. (2008). Integrating drivers influencing the detection of plant pests carried in the international cut flower trade. Journal of Environmental Management, 89, 300-307. http://dx.doi.org/10.1016/j.jenvman.2007.06.017

Barrett, C. (2008). Smallholder market participation: Concepts and evidence from eastern and southern Africa. Food Policy, 34, 299-317.

Barrett, C., \& Swallow, B. (2006). An ordered Tobit model of market participation: Evidence from Kenya and $\begin{array}{llll}\text { Ethiopia. American Journal of Agricultural Economic, } & 88(2), & 324-337 .\end{array}$ http://dx.doi.org/10.1111/j.1467-8276.2006.00861.x

Berk, R., \& MacDonald, J. (2007). Over dispersion and Poisson Regression "Ensemble methods for DataAnalysis in the Behavioural, Social and Economic Sciences.

Clague, C. (1997). The New Institutional Economics and Economic Development, in Clague, C (Ed); Institutions and Economic Development: Growth and Governance in Less-Developed and Post-Socialist Countries. Baltimore: The John Hopkins University Press

Coase, R.H. (1937). The Nature of the Firm. Economica, 4, 386-405. http://dx.doi.org/10.1111/j.1468-0335.1937.tb00002.x

Fafchamps, M. (2004). Market institutions in sub-Saharan Africa. Cambridge, M.A: MIT Press.

Fafchamps, M., \& Hill, R.V. (2005). Selling at the farm gate or travelling to the market. American Journal of Agricultural Economics, 87(3), 717-734. http://dx.doi.org/10.1111/j.1467-8276.2005.00758.x

Fafchamps, M., \& Gabre-Madhin, E. (2006). Agricultural markets in Benin and Malawi. African Journal of Agricultural and Resource Economics, 1(1), 67 - 94

Famoye, F., Wulu J.T., \& Singh, K.P. (2005). On the Generalized Poisson Regression Model with an Application to Accident Data, Journal of Data Science, 2(2004), 287-295.

Gabre-Madhin, E. (2006). Agricultural markets in Benin and Malawi. African Journal of Agricultural and Resource Economics, 1(1), 67 - 94.

Greene, H. W. (2003). Econometric Analysis: Pearson Education Inc. New York University.

Greene, H.W. (2007). Functional Form and Heterogeneity in Models for Count Data: Department of Economics, Stern School of Business, New York University.

Greene, W. (2008). Functional forms for the negative binomial model for count data. Economics Letters, 99, 585-590. http://dx.doi.org/10.1016/j.econlet.2007.10.015

Gujarati D.N. (2004). Basic Econometrics. (4 ${ }^{\text {th }}$ ed) New York: McGraw-Hill.

Hubbard, M. (1997). The “New Institutional Economics' in Agricultural Development: Insights and Challenges. Journal of Agricultural Economics, 48, (20), 239-250. http://dx.doi.org/10.1111/j.1477-9552.1997.tb01148.x

Jaffe, S. (2005). Transaction costs, risk and the organization of private sector food commodity systems In: Jaffee,

S. and Morton, J. (eds). Marketing Africa's High-Value Foods: Comparative Experiences of an Emergent Private Sector, Dubuque, Iowa.

Kirui, O.K., Okello, J.J. \& Nyikal, R.A. (2010). Awareness, use and effect of mobile phone-based money transfer in Kenyan agriculture. A paper presented at African Association of Agricultural Economics Conference, Cape Town, South Africa, 20-23 September, 2010. 
Liao, T. (1994). Interpreting Probability Models: Logit, Probit, and Other Generalized Linear Models. Thousand Oaks, CA: Sage.

Maddalla, G.S. (2001). Limited Dependent and Quantitative Variables in Econometrics. Cambridge: Cambridge University Press.

Menard, C. (2005). A new institutional approach to organization. In C. Menard and M.M. Shirley, Handbook of New Institutional Economics, (pp 281-318) Dorcdrecht, The Netherlands, Springer. http://dx.doi.org/10.1007/0-387-25092-1_13

Munyua, H. (2007). ICTs and small scale agriculture in Africa: a scoping study. Draft Report 1 Submitted to International Development Research Center.

Okello, J.J., Ofwona-Adera, E., Mbatia, O.L.E, \& Okello, R.M. (2010). Using ICT to integrate smallholder farmers into agricultural value chain; The case of DrumNet project in Kenya. International Journal of ICT and Research Development, 1, 23-37. http://dx.doi.org/10.4018/jictrda.2010010102

Okello, J.J, \& S.M. Swinton. (2007). Compliance with international food safety standards in Kenya's green bean industry: A paired case study of small and large family farms. Review of Agricultural Economics, 29, 269-285. http://dx.doi.org/10.1111/j.1467-9353.2006.00342.x

Okello, J.J. (2005). Compliance with International Food Safety Standards: The Case of Green Bean Production in Kenyan Family Farms. PhD Dissertation, Michigan State University.

Omamo, S.W., (1998). Farm-to-market transaction costs and specialization in smallscale agriculture: explorations with non-separable household model. Journal of Development Studies, 35, 152-163. http://dx.doi.org/10.1080/00220389808422568

Poulton, C., Dorward, A., \& Kydd, J. (1998). The Revival of Smallholder Cash Crop in Africa: Public and Private Roles in the Provision of Finance. Journal of international Development, 10(1), 85-103. http://dx.doi.org/10.1002/(SICI)1099-1328(199801)10:1<85::AID-JID502>3.0.CO;2-V

Poulton, C., Kydd, J, \& Doward, A. (2006). Overcoming market constraints on pro-poor Agricultural growth in sub-saharan Africa, Development Policy Review, 24(3), 243-27. http://dx.doi.org/10.1111/j.1467-7679.2006.00324.x

Shiferaw, B., Obare, G., \& Muricho, G. (2009). Rural institutions and producer organizations in imperfect markets: Experiences from producer marketing groups in semi arid eastern Kenya. Journal of SAT Agricultural Research, 2(1), 37- . Available at www.ejournal.icrisat.org/mpiirpaper2.1.htm.

Sirak, M., \& Rice, J.C. (1994). Logistic Regression: An Introduction. In B. Thompson, ed., Advances in Social Science Methodology, 3 (pp 191-245). Greenwich, CT: JAI Press.

Tobin, J. (1958). Estimation on Relationship for Limited Dependent Variables, Econometrica, 26, 26-36. http://dx.doi.org/10.2307/1907382

Tollens, E. F. (2006). Market information systems in sub-Sahara Africa challenges and opportunities. Poster paper prepared for presentation at the International Association of Agricultural Economists Conference, Gold Coast, Australia August 12-18, 2006.

Williamson, O. E. (1975). Markets and hierarchies: Analysis and anti-trust implications. New York: The Free Press.

Williamson, O.E. (1985). The economic institutions of capitalism: Firms, markets, relational contracting. New York: The Free Press.

Williamson, O.E. (2000). The New Institutional Economics: Taking Stock, Looking Ahead. Journal of Economic Literature, 38(3), 595-613. http://dx.doi.org/10.1257/jel.38.3.595

Williamson, O.E. (2000). Examining Economic Organization Through the Lens of Contract. Industrial and Corporate Change, 12 (4), 917-942. http://dx.doi.org/10.1093/icc/12.4.917

Winkelman, R., \& Zimmerman, K.F. (1995). Recent developments in count data modelling; theory and applications. Journal of economic surveys, 9, 1-24. http://dx.doi.org/10.1111/j.1467-6419.1995.tb00108.x

Woodridge, J.M. (2002). Econometric analysis of cross sectional data and panel data. Cambridge and London: MIT press. 
Table 1. Definitions of variables used in the empirical estimations

\begin{tabular}{|c|c|}
\hline Variable name & Variable Definition \\
\hline \multicolumn{2}{|c|}{ Dependent variables } \\
\hline useicttool & 1 If a farmer uses ICT tools in agriculture, 0 otherwise \\
\hline usemphone & 1 if a farmer uses a mobile phone for agricultural transactions, 0 otherwise \\
\hline Totcalls & Total calls made for agricultural transactions \\
\hline \multicolumn{2}{|c|}{ Independent variables } \\
\hline \multicolumn{2}{|c|}{ Farmer/household specific variables } \\
\hline lnage & Natural log of age of household head (years) \\
\hline hhsize & Size of the household (number of household members) \\
\hline gender & 1 if household head is male, 0 otherwise \\
\hline occupation & 1 if main occupation of the farmer is farming 0 otherwise \\
\hline literacy & 1 if a member can read and write, 0 otherwise \\
\hline \multicolumn{2}{|c|}{ Farm-specific variables } \\
\hline fare & Transport cost to a produce market in Kenya Shillings \\
\hline dist electr & Distance to the nearest electricity hook-up (km) \\
\hline numcropent & Number of crop enterprises within the farm (count) \\
\hline \multicolumn{2}{|c|}{ Capital endowment variables } \\
\hline ownphone & If a member has a working mobile phone or simcard \\
\hline area & Total land area (acres) cultivated during 2009. \\
\hline lnexper & Natural log of years of farming \\
\hline lnassets & Natural log of value of assets measured in Kenya Shillings* \\
\hline Incropincome & Natural log of crop income measured in Kenya Shillings \\
\hline grpmember & 1 if farmer is member of a farmer organization, 0 otherwise \\
\hline \multicolumn{2}{|c|}{ Regional dummies } \\
\hline Kirinyaga & 1 if the farmer is located in Kirinyaga district, 0 otherwise \\
\hline Migori & 1 if the farmer is located in Migori district, 0 otherwise \\
\hline Bungoma & 1 if the farmer is located in Bungoma district, 0 otherwise \\
\hline
\end{tabular}

The exchange rate was Kshs $78=1$ US dollar at the time of survey 
Table 2. Summary statistics of variables used in empirical estimations

\begin{tabular}{|c|c|c|c|c|}
\hline \multirow[b]{2}{*}{ Variable definition } & & \multicolumn{3}{|c|}{ t-test of means } \\
\hline & Mean & $\begin{array}{l}\text { Standard } \\
\text { deviation }\end{array}$ & t-statistic & p-values \\
\hline \multicolumn{5}{|l|}{ Dependent variables } \\
\hline Totcalls & 6.094 & 7.507 & 34.497 & 0.000 \\
\hline useicttools & 0.469 & 0.499 & -1.218 & 0.223 \\
\hline usemphone & 0.464 & 0.499 & - & \\
\hline \multicolumn{5}{|c|}{ Independent variables } \\
\hline \multicolumn{5}{|c|}{ Farmer/Household specific variables } \\
\hline lnage & 3.722 & 0.318 & 1.278 & 0.781 \\
\hline hhsize & 5.746 & 2.162 & 4.564 & 0.000 \\
\hline gender & 0.506 & 0.500 & -2.662 & 0.008 \\
\hline occupation & 0.894 & 0.307 & -0.192 & 0.847 \\
\hline \multicolumn{5}{|c|}{ Farm-specific variables } \\
\hline Fare & 49.823 & 36.835 & -5.481 & 0.000 \\
\hline distelectric & 2.700 & 3.658 & 1.299 & 0.194 \\
\hline numcropenter & 2.910 & 1.516 & -1.345 & 0.179 \\
\hline \multicolumn{5}{|c|}{ Capital endowment variables } \\
\hline literacy & 0.849 & 0.357 & -4.835 & 0.000 \\
\hline ownphone & 0.635 & 0.481 & -6.056 & 0.000 \\
\hline lnexper & 2.613 & 0.825 & -0.767 & 0.443 \\
\hline lnassets & 10.571 & 1.420 & -3.387 & 0.000 \\
\hline area & 6.269 & 7.005 & -1.213 & 0.225 \\
\hline Incropincome & 7.852 & 4.209 & -5.251 & 0.000 \\
\hline grpmember & 0.617 & 0.486 & -2.414 & 0.016 \\
\hline \multicolumn{5}{|l|}{ Regional dummies } \\
\hline Kirinyaga & 0.335 & 0.472 & -5.643 & 0.000 \\
\hline Migori & 0.321 & 0.467 & 3.961 & 0.000 \\
\hline Bungoma & 0.343 & 0.475 & 1.600 & 0.110 \\
\hline
\end{tabular}


Table 3. Factors affecting the decision to use ICT tools for agricultural transactions: Logit regression

\begin{tabular}{|c|c|c|c|c|}
\hline \multirow{3}{*}{ Variable definition } & \multicolumn{4}{|c|}{$\begin{array}{l}\text { Dependent variable: Farmer uses ICT tools for agricultural } \\
\text { transactions }\end{array}$} \\
\hline & \multicolumn{2}{|l|}{ Logit regression } & \multicolumn{2}{|c|}{ Marginal effects } \\
\hline & Coefficient & $\mathrm{p}$-value & Coefficient & p-value \\
\hline \multicolumn{5}{|c|}{ Farmer-specific variables } \\
\hline lnage & -1.192 & 0.053 & -0.296 & 0.054 \\
\hline gender & 0.197 & 0.479 & 0.049 & 0.477 \\
\hline occupation & 1.117 & 0.020 & 0.251 & 0.005 \\
\hline \multicolumn{5}{|c|}{ Farm-specific variables } \\
\hline hhsize & -0.072 & 0.321 & -0.018 & 0.322 \\
\hline disteletric & 0.080 & 0.029 & 0.019 & 0.029 \\
\hline fare & 0.008 & 0.021 & 0.002 & 0.021 \\
\hline numcropenter & -0.193 & 0.040 & -0.048 & 0.040 \\
\hline \multicolumn{5}{|c|}{ Capital endowment variables } \\
\hline literacy & 0.664 & 0.097 & 0.159 & 0.078 \\
\hline lnexper & 0.418 & 0.088 & 0.103 & 0.087 \\
\hline area & 0.001 & 0.933 & 0.000 & 0.933 \\
\hline ownphone & 0.239 & 0.401 & 0.059 & 0.398 \\
\hline lncropincome & 0.070 & 0.032 & 0.017 & 0.032 \\
\hline Lnassets & -0.191 & 0.045 & -0.047 & 0.045 \\
\hline grpmember & 0.418 & 0.139 & 0.103 & 0.135 \\
\hline \multicolumn{5}{|c|}{ Regional characteristics } \\
\hline Kirinyaga & 2.873 & 0.000 & -.580 & 0.000 \\
\hline Migori & -2.198 & 0.000 & -0.474 & 0.000 \\
\hline \multirow[t]{2}{*}{ Constant } & 4.671 & 0.057 & & \\
\hline & \multicolumn{2}{|c|}{$\begin{array}{l}\text { Number of obs }=379 \\
\text { Log likelihood }=-201.234\end{array}$} & \multicolumn{2}{|c|}{$\begin{array}{l}\text { Prob }>\mathrm{chi}^{2}=0.000 \\
\text { Pseudo } \mathrm{R}^{2}=0.232\end{array}$} \\
\hline
\end{tabular}


Table 4. Drivers of use and intensity of use of mobile phone for agricultural transactions: Double-hurdle regression model

\begin{tabular}{|c|c|c|c|c|c|c|c|c|}
\hline \multirow{3}{*}{$\begin{array}{l}\text { Variable } \\
\text { definition }\end{array}$} & \multicolumn{4}{|c|}{$\begin{array}{l}1^{\text {st }} \text { hurdle (decision to use mobile phone for } \\
\text { agricultural purposes) } \\
\text { Dependent variable: Use of mobile phone }\end{array}$} & \multicolumn{4}{|c|}{$\begin{array}{l}2^{\text {nd }} \text { hurdle (Intensity of using mobile phone) } \\
\text { Dependent variable: Number of calls made for } \\
\text { agricultural transactions }\end{array}$} \\
\hline & \multicolumn{2}{|c|}{ Logit regression } & \multicolumn{2}{|c|}{ Marginal effects } & \multicolumn{2}{|c|}{ Poisson regression } & \multicolumn{2}{|c|}{ Marginal effects } \\
\hline & Coefficient & $\mathrm{p}$-value & Coefficient & p-value & Coefficient & $\mathrm{p}$-value & Coefficient & $\mathrm{p}$-value \\
\hline \multicolumn{9}{|l|}{$\begin{array}{l}\text { Farmer-specific } \\
\text { variables }\end{array}$} \\
\hline lnage & -1.440 & 0.034 & -0.353 & 0.034 & -0.347 & 0.281 & -1.553 & 0.278 \\
\hline gender & 0.672 & 0.017 & 0.163 & 0.015 & 0.229 & 0.055 & 1.023 & 0.057 \\
\hline occupation & -.074 & 0.863 & -0.018 & 0.864 & 0.110 & 0.597 & 0.471 & 0.581 \\
\hline \multicolumn{9}{|l|}{$\begin{array}{l}\text { Farm-specific } \\
\text { variables }\end{array}$} \\
\hline hhsize & -0.224 & 0.003 & -0.055 & 0.003 & -0.122 & 0.001 & -0.549 & 0.001 \\
\hline distelectric & -0.005 & 0.873 & -0.001 & 0.873 & -0.001 & 0.966 & -0.004 & 0.966 \\
\hline fare & 0.019 & 0.000 & 0.004 & 0.000 & 0.008 & 0.000 & 0.037 & 0.000 \\
\hline \multicolumn{9}{|l|}{$\begin{array}{l}\text { Capital } \\
\text { endowment } \\
\text { variables }\end{array}$} \\
\hline literacy & 0.371 & 0.004 & 0.290 & 0.000 & 1.018 & 0.001 & 3.325 & 0.000 \\
\hline lnexper & 0.464 & 0.053 & 0.113 & 0.053 & 0.178 & 0.162 & 0.796 & 0.160 \\
\hline area & -0.010 & 0.677 & -0.002 & 0.676 & -0.019 & 0.253 & -0.087 & 0.251 \\
\hline ownphone & 1.027 & 0.000 & 0.241 & 0.000 & 0.440 & 0.002 & 1.867 & 0.001 \\
\hline lncropincome & 0.104 & 0.002 & 0.025 & 0.002 & 0.053 & 0.003 & 0.236 & 0.002 \\
\hline lnassets & 0.275 & 0.007 & 0.067 & 0.007 & 0.144 & 0.001 & 0.644 & 0.001 \\
\hline $\begin{array}{l}\text { grpmember } \\
\text { Regional } \\
\text { characteristics }\end{array}$ & 0.319 & 0.269 & 0.077 & 0.263 & 0.123 & 0.324 & 0.543 & 0.315 \\
\hline kirinyaga & -.180 & 0.624 & -.044 & 0.622 & -0.200 & 0.161 & -1.869 & 0.146 \\
\hline Migori & -1.395 & 0.001 & -0.315 & 0.000 & -0.666 & 0.001 & -2.691 & 0.000 \\
\hline \multirow[t]{2}{*}{ Constant } & -1.116 & 0.603 & & & 0.244 & 0.828 & & \\
\hline & \multicolumn{2}{|c|}{$\begin{array}{l}\text { Number of obs }=379 \\
\text { Log likelihood=-189.28 }\end{array}$} & \multicolumn{2}{|c|}{$\begin{array}{l}\text { Prob }>\text { chi }^{2}=0.000 \\
\text { Pseudo } R^{2}=0.276\end{array}$} & \multicolumn{2}{|c|}{$\begin{array}{l}\text { Number of obs }=379 \\
\text { Log likelihood=-1751.63 }\end{array}$} & \multicolumn{2}{|c|}{$\begin{array}{l}\text { Prob }>\mathrm{chi}^{2}=0.000 \\
\text { Pseudo } \mathrm{R}^{2}=0.2599\end{array}$} \\
\hline
\end{tabular}

